\title{
Platelet-derived Growth Factor Activity and mRNA Expression in Healing Vascular Grafts in Baboons \\ Association In Vivo of Platelet-derived Growth Factor mRNA and Protein with Cellular Proliferation
}

\author{
Michael A. Golden, ${ }^{*}$ Y. P. Tina Au, ${ }^{*}$ Thomas R. Kirkman, ${ }^{\star}$ Josiah N. Wilcox, ${ }^{*}$ \\ Elaine W. Raines, ${ }^{3}$ Russell Ross, ${ }^{*}$ and Alexander W. Clowes* \\ *Department of Surgery, University of Washington, Seattle, Washington 98915 ; $^{\ddagger}$ Department of Cardiovascular Research, Genentech, \\ Inc., South San Francisco, California 94080; and ${ }^{\S}$ Department of Pathology, University of Washington, Seattle, Washington 98195
}

\begin{abstract}
In a baboon graft model of arterial intimal thickening, smooth muscle cells (SMC) have been observed to proliferate underneath an intact monolayer of endothelium and in the absence of platelet adherence. Because platelets are not present and therefore cannot be a major source of growth stimulus, we have proposed that the vascular wall cells in the graft intima express mitogens and regulate SMC proliferation. To test this hypothesis, we assayed the grafts for mitogenic activity and expression of growth factor genes. Segments of healing graft and of normal artery, when perfused ex vivo, released mitogenic activity into the perfusate. The graft released more mitogen than the normal arterial segment, and some of the activity was inhibitable with an antibody to human platelet-derived growth factor (PDGF). In addition, Northern analysis of total RNA demonstrated higher expression of PDGF-A chain mRNA in the graft intima compared to normal artery. PDGF-B chain mRNA was barely detectable in both tissues. PDGF mRNA levels within the graft interstices were not measured. In situ hybridization of 7.5- or 12-wk grafts indicated that some luminal endothelial cells and adjacent intimal SMC contained PDGF-A chain mRNA. By thymidine autoradiography, intimal SMC were observed to be proliferating in the inner third of the intima. These data demonstrate a difference in the pattern of PDGF transcript expression and luminal perfusate activity in graft as compared with control arteries. The association of intimal smooth muscle cell proliferation with intimal PDGF $m$ RNA expression and release of PDGF-like protein supports the hypothesis that factors from cells that have grown into the graft or populated its surface rather than platelets may regulate intimal smooth muscle cell proliferation in this model. (J. Clin. Invest. 1991.87:406-414.) Key words: smooth muscle cell • endothelium • intimal hyperplasia
\end{abstract}

\section{Introduction}

A number of growth factors for vascular smooth muscle cells $(\mathrm{SMC})^{1}$ have been isolated and characterized. Despite the

Address reprint requests to Alexander W. Clowes, M.D., Department of Surgery, RF-25, University of Washington, Seattle, WA 98195.

Received for publication 7 November 1989 and in revised form 9 August 1990

1. Abbreviations used in this paper: FGF, fibroblast growth factor; PDGF, platelet-derived growth factor; SMC, smooth muscle cell.

J. Clin. Invest.

(C) The American Society for Clinical Investigation, Inc.

0021-9738/91/02/0406/09 \$2.00

Volume 87, February 1991, 406-414 abundance of information regarding growth factors and their secretion by cells in culture, there is limited evidence in vivo that these growth factors play a role in regulating the proliferation of SMC in either the normal artery during growth and development or in diseased vessels with lesions of atherosclerosis.

Studies of human lesions and experimental models of atherosclerosis have suggested a regulatory role for platelet-derived growth factor (PDGF), a potent smooth muscle cell mitogen released by platelets and other arterial cells after activation (1). PDGF mRNA has been identified by Northern analysis in human atherosclerotic plaques (2). Increased levels of PDGF-B mRNA were correlated with increased expression of c-fms (a macrophage-specific marker) and to a lesser extent $(\sim 10 \%)$ with von Willebrand factor (an endothelial-specific marker) (3). PDGF-B chain protein has been observed mainly in nonlipid containing macrophages in both human and nonhuman primate lesions of atherosclerosis at all stages of development (4). In addition, in endarterectomy specimens containing very advanced fibrotic lesions of atherosclerosis, PDGF-B chain message has been demonstrated in endothelial cells by in situ hybridization, whereas PDGF-A chain and the PDGF- $\beta$ receptor subunit message appears to be expressed by mesenchymal cells (possibly SMC) (5). In a rat model of intimal SMC proliferation, SMC in the media of an injured carotid artery express PDGF-A chain mRNA; at later times SMC migrate into the intima and express mRNA for the beta type of PDGF receptor (6). In addition to mRNA for PDGF-A chain, cultured SMC derived from human atheroma are capable of producing a PDGF-like protein (7). Although immunohistochemical techniques have demonstrated pronounced expression of PDGF beta receptor in vascular SMC in atherosclerotic plaques, the receptor is not expressed or is expressed at low levels in normal vessels (8). None of these studies, however, proves that the PDGF expression or protein present in the lesions are responsible for the proliferation of SMC in vivo.

To evaluate the factors responsible for SMC proliferation and wall thickening in normal and diseased arteries, we have studied a baboon arterial graft model of intimal thickening. In this model (9), the first event in the healing process is endothelial coverage. After the endothelium has been fully established, SMC appear in the intima and begin to proliferate beneath the endothelium in the absence of platelet adhesion. These observations are consistent with the hypothesis that the vascular wall cells present in the graft intima or within the pores of the graft synthesize growth factors, and that the SMC response to these growth factors is not dependent on factors released from platelets. In this report we show an association between the expression and release of PDGF and SMC proliferation within the intima of healing baboon arterial grafts. 


\section{Methods}

Graft implantation. Polytetrafluoroethylene 4-mm-internal-diameter, $60-\mu \mathrm{m}$-internodal distance grafts (W. L. Gore \& Associates, Inc., Flagstaff, AZ) $6 \mathrm{~cm}$ long were placed bilaterally in the aortoiliac circulation of 10-kg, 2-yr-old baboons (Papio cynocephalus). The animals were given halothane general anesthesia and the procedures were performed with aseptic technique. Before cross-clamping the native arteries, $10 \mathrm{cc}$ of whole blood were drawn and used to preclot the grafts. The animals were then given 2,500 $\mathrm{U}$ of heparin sodium intravenously, and on each side, a graft was anastomosed proximally to the distal aorta, and distally to the proximal external iliac artery with continuous $6-0$ polypropylene suture (David \& Geck, Wayne, NJ). Ligatures were placed to interrupt the native arterial circulation just distal to the proximal anastomoses and just proximal to the distal anastomoses, without disturbing the inflow or outflow of the grafts.

The grafts and comparable lengths of aorta and carotid artery were removed from the animals at $2 \mathrm{wk}, 1 \mathrm{mo}$, and $3 \mathrm{mo}$ after implantation.

Ex vivo perfusion. From heparinized animals under general anesthesia, graft and arterial segments measuring $\sim 4 \mathrm{~cm}$ in length were removed, rinsed with PBS, and tied off at both ends after filling the lumen with perfusion medium. The perfusion medium was $25 \mathrm{mM}$ Hepes buffered Ham's F12 medium (pH 7.4) (Gibco, Grand Island, NY) with $2 \%$ calf serum CMS-1. The calf serum had been treated with CM-Sephadex (C-50, Pharmacia Fine Chemicals, Piscataway, NJ) to remove any cationic growth factor (10). The graft segments were then tied to a sterile glass slide and immersed in the same medium. Segments of common carotid artery or thoracic aorta were treated in the same fashion. Cannulae (23-gauge butterfly needle, Abbott Laboratories, No. Chicago, IL) were placed at each end of the graft and arterial segments. They were perfused with the medium described above at $3 \mathrm{ml} / \mathrm{h}$ at $37^{\circ} \mathrm{C}$, and perfusate was collected in serial fractions and frozen at $-70^{\circ} \mathrm{C}$. During the perfusion, the segments of graft and control artery were immersed in the same medium used for perfusion.

Mitogenesis assay. The mitogenic activity in the perfusates from the graft segments and arterial controls was evaluated by measuring ${ }^{3} \mathrm{H}$-thymidine incorporation into DNA of human fibroblasts $18-20 \mathrm{~h}$ after sample addition as previously described (10). The sample added to each dish was $100 \mu \mathrm{l}$ aliquot of thawed perfusate (collected between 8 and $22 \mathrm{~h}$ after starting perfusion ex vivo). Each perfusate sample was tested in triplicate. The mean counts per minute for each triplicate was normalized to the luminal surface area of the perfused conduit, and the mitogenic activity of the graft perfusate was compared with that of the control artery perfusate from the same animal. Fibroblasts were used to evaluate the mitogenic activity of the perfusates to provide a consistent assay system during the course of the studies $(\sim 1 \mathrm{y})$. Although both baboon and human smooth muscle cells are used in the laboratories, the variation in the basal cell proliferation and the fold stimulation by exogenously added mitogens would have made such a comparative study much more difficult.

A polyclonal goat anti-PDGF blocking antibody was added at the concentration of $500 \mu \mathrm{g} / \mathrm{ml}$ to the perfusate in the mitogenesis assay and the results were compared to those of the same perfusate containing nonimmune $\operatorname{IgG}(11)$. The goat anti-PDGF IgG used in these experiments was prepared by immunizing a goat with human platelet PDGF. Human PDGF is a mixture of all three dimeric forms of PDGF. This IgG neutralizes all three dimeric forms of PDGF but requires higher concentrations to inhibit PDGF-AA $(0.8 \mathrm{mg} / \mathrm{ml}$ to inhibit 1 $\mathrm{ng} / \mathrm{ml}$ of exogenously added PDGF-AA as compared with $0.2 \mathrm{mg} / \mathrm{ml}$ to inhibit $1 \mathrm{ng} / \mathrm{ml}$ of exogenously added PDGF-AB or PDGF-BB). Since the level of mitogenic activity detected in the perfusate was equivalent to $0.5 \mathrm{ng} / \mathrm{ml}$ (as compared to a standard curve with purified PDGF-AB), the use of $500 \mu \mathrm{g} / \mathrm{ml}$ of anti-PDGF $\mathrm{IgG}$ was necessary to insure neutralization of all dimeric forms (12). By immunoprecipitation, neutralization of mitogenesis, and ELISA, we could not detect cross-reactivity with acidic and basic fibroblast growth factor, epidermal growth factor, transforming growth factor $\alpha$, transforming growth factor $\beta$, or insulin-like growth factor I. Both the anti-PDGF IgG and the nonimmune IgG were purified from plasma and were therefore devoid of platelet growth factors and had no endogenous mitogenic activity at the doses used in these experiments.

Assays for platelet factor 4 (PF4), beta-thromboglobulin (beta-TG), and lactate dehydrogenase ( $L D H)$. Samples of perfusate collected from control arteries and from grafts were examined by radioimmunoassay for content of PF4 (Abbot Laboratories, No. Chicago, IL) and beta-TG (Amersham Corp., Arlington Heights, IL). A chromogenic activity assay (Macomb, Romeo, MI) was used to determine the LDH content in the perfusates from both graft and artery.

$R N A$ extraction and Northern analysis. The graft was quickly removed, rinsed with $0.9 \% \mathrm{NaCl}$, and cut open. The intima was stripped from the graft matrix and immediately frozen in liquid nitrogen. Three grafts were analyzed at each time point. The thoracic aorta was also removed, rinsed, and immediately frozen in liquid nitrogen.

The frozen intima and aortic tissue was ground to a fine powder with a mortar and pestle cooled with liquid $\mathrm{N}_{2}$ and then homogenized with a polytron in buffer containing $5 \mathrm{M}$ guanidine isothiocyanate, 10 mM EDTA, $50 \mathrm{mM}$ Tris- $\mathrm{HCl}$, pH 7.5, and $8 \%$ (vol/vol) $\beta$-mercaptoethanol (13). RNA was not extracted from graft matrix. All reagents were molecular biology grade. Total RNA was selectively precipitated by the addition of lithium chloride according to the procedure of Cathala et al. (12). $10 \mu \mathrm{g}$ of total RNA sample was electrophoresed in $1 \%$ agarose and transferred to nylon membranes (Zetaprobe; Bio-Rad Laboratories, Richmond, CA) for Northern analysis (14). Human PDGFA (1.3-kb Eco RI human cDNA fragment) (15) or PDGF-B (1.2-kb PST I fragment of $\mathrm{v}$-sis) (16) cDNA probe labeled with ${ }^{32} \mathrm{P}$ by nick translation (17) was added to the hybridization solution (50\% formamide in $0.14 \mathrm{M}$ sodium phosphate buffer, $\mathrm{pH} 7.2$, containing $0.25 \mathrm{M}$ $\mathrm{NaCl} / 7.0 \% \mathrm{SDS} / 1 \mathrm{mM}$ EDTA/10\% polyethylene glycol) at $2 \times 10^{6}$ $\mathrm{cpm} / \mathrm{ml}$. Hybridization was performed at $42^{\circ} \mathrm{C}$ for $20-24 \mathrm{~h}$. After hybridization, the blots were washed in $2 \times \mathrm{SSC} / 0.1 \% \mathrm{SDS}$ at room temperature for $30 \mathrm{~min}$, followed by $0.1 \times \mathrm{SSC} / 0.1 \% \mathrm{SDS}$ at $65^{\circ} \mathrm{C}$ for 10-15 $\mathrm{min}$. Signals were detected by autoradiography and quantitated by densitometry.

In situ hybridization. Probes specific to human PDGF A chain (14) or PDGF B chain (18) were labeled by transcription (19) using ${ }^{35}$ S-labeled UTP (specific activity, 1,200 Ci/mmol; Amersham Corp., Arlington, IL). Full-length antisense transcripts were used for hybridization. The final specific activity of these probes was $300 \mathrm{Ci} / \mathrm{mmol}$.

In situ hybridization was performed as previously described $(5,20)$. Briefly, cryosections were pretreated with paraformaldehyde, proteinase K (Sigma Chemical Co., St. Louis, MO), and prehybridized in 100 $\mu$ l hybridization buffer ( $50 \%$ formamide, $0.3 \mathrm{M} \mathrm{NaCl}, 20 \mathrm{mM}$ Tris, $\mathrm{pH}$ 8.0, $5 \mathrm{mM}$ EDTA, $0.02 \%$ polyvinylpyrrolidine, $0.02 \%$ Ficoll, $0.02 \%$ BSA, $10 \%$ dextran sulfate, and $10 \mathrm{mM}$ dithiothreitol) at $42^{\circ} \mathrm{C}$. Serial sections were hybridized by addition of $600,000 \mathrm{CPMs}$ of ${ }^{35} \mathrm{~S}$-labeled PDGF-A or -B chain riboprobes and incubation overnight at $55^{\circ} \mathrm{C}$. After hybridization, the sections were washed with $2 \times$ SSC $(1 \times$ SSC $=150 \mathrm{mM} \mathrm{NaCl}, 15 \mathrm{mM} \mathrm{Na}$ citrate, $\mathrm{pH} 7.0$ ) with $10 \mathrm{mM} \beta$-mercaptoethanol and $1 \mathrm{mM}$ EDTA, treated with RNase (Sigma Chemical Co.), followed by a high-stringency wash in $0.1 \times$ SSC with $10 \mathrm{mM}$ $\beta$-mercaptoethanol and $1 \mathrm{mM}$ EDTA, at $55^{\circ} \mathrm{C}$. The slides were then washed in SSC without $\beta$-mercaptoethanol, dehydrated in graded alcohols containing $0.3 \mathrm{M} \mathrm{NH}_{4} \mathrm{Ac}$, dried, coated with NTB2 nuclear track emulsion (Eastman Kodak Co., Rochester, NY), and exposed in the dark at $4^{\circ} \mathrm{C}$ for $4-12$ weeks. After development, the sections were counterstained with hematoxylin and eosin to aid in cell identification.

Immunohistochemistry. Monoclonal antibodies were used, as described previously, to identify cell types in the graft (21). Paraffin-embedded tissue sections were stained using the biotin-avidin-peroxidase technique with diaminobenzidene- $\mathrm{NiCl}_{2}$ as the chromogen (22). Endothelial cells were identified by punctate staining with a polyclonal rabbit antibody to human factor VIII-related antigen (Dako Corp., Santa Barbara, CA) (23). SMC stained with a mouse monoclonal antibody (HHF 35) against human smooth muscle-specific actin isotypes (24), 
and macrophages were identified with a mouse monoclonal antibody to human macrophages (HAM 56) (24a); these monoclonal antibodies were a gift of Dr. Allen Gown.

Thymidine autoradiography. Three animals were killed 1 mo after receiving three doses of tritiated thymidine $(0.5 \mathrm{mCi} / \mathrm{kg}$ per dose $)$ (New England Nuclear, Boston, MA) by intramusclar injection (9). One-half hour before fixation, heparin $(3,000 \mathrm{U})$ and Evans blue $(50 \mathrm{mg} / \mathrm{kg})$ were given by intravenous injection. The animals were killed by anesthetic overdose, and their arteries were fixed by perfusion with $2.5 \%$ glutaraldehyde in $0.1 \mathrm{mM}$ phosphate buffer, $\mathrm{pH} 7.4$, at $100 \mathrm{mmHg}$. The grafts were excised, further fixed by immersion, and then washed extensively. Rings of graft were embedded in paraffin and cross-sectioned. Unstained deparaffinized histologic sections were dipped in Kodak NTB 2 emulsion, allowed to dry, and kept at $4^{\circ} \mathrm{C}$ in light-tight boxes for 2 wk. Slides were developed in Kodak D-19 developer and fixed. After staining with hematoxylin, the autoradiograms were evaluated at high power $(100 \times)$ to determine the distribution of labeled SMC in the intima.

\section{Results}

The time course of graft healing. The morphologic and autoradiographic characteristics of graft healing were reported previously $(9,21,25)$. Briefly, after implantation of the grafts, the surface is covered by a layer of thrombus. Subsequently, capillaries and microvessels from the surrounding granulation tissue penetrate the graft matrix and provide multiple sources of endothelium and SMC to cover the luminal surface. The luminal surface of the graft becomes lined with endothelial cells by two weeks. Beneath the endothelium, SMC appear and begin to proliferate, accumulate, and form connective tissue matrix creating a thickened intima. The thickness of the intima increases until 3 mo after graft implantation. After $2 \mathrm{wk}$, the predominant cell type in the intima is the SMC. Within the interstices of the porous graft material, there are large numbers of macrophages (Fig. 1). Occasional macrophages are also found in the intima. Tritiated thymidine autoradiographs of healing grafts 1 and 3 mo after graft implantation demonstrate SMC proliferation, with an intimal SMC labeling index measuring 5-100-fold above that of native arterial SMCs (9). At the same times, the endothelial cells are proliferating with a labeling index that is $10-100$-fold above that of normal arterial endothelium.

An analysis of the distribution of tritiated thymidine labeled SMC in histologic cross-sections demonstrates that threefourths of the proliferating SMC are in the inner one-third of the intima adjacent to the endothelium (inner third, $75 \pm 3 \%$; middle third, $19 \pm 4 \%$; outer third, $6 \pm 3 \%$ [mean $\pm \mathrm{SD} ; n=3$ ]) (Fig. 2). The proximity of the proliferating SMC to the endothelium and the absence of platelets at this stage of healing in the graft led us to investigate whether the endothelial cells might regulate the SMC growth, and whether growth factors might be detectable in fluid perfused through the lumen of the graft ex vivo.

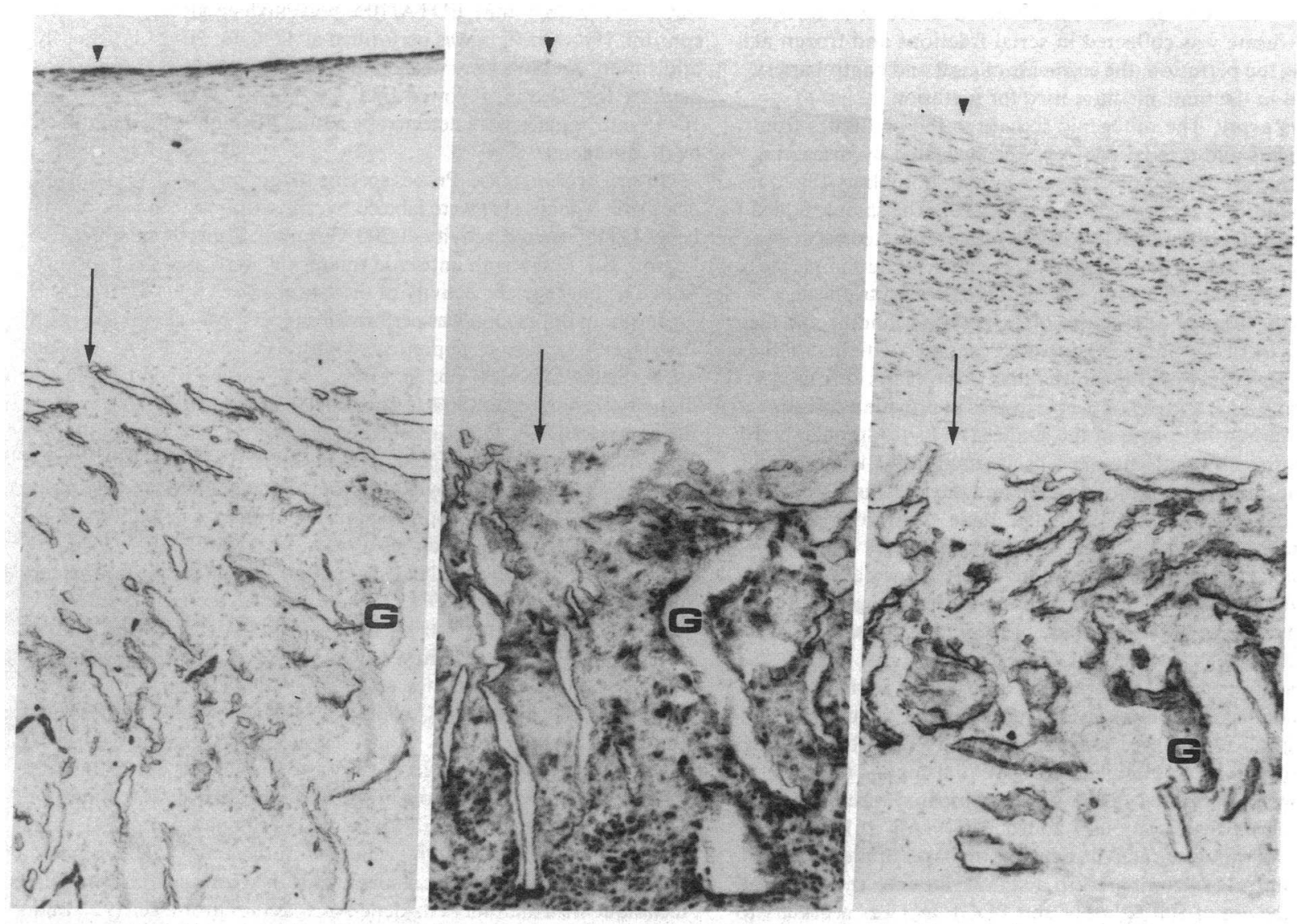

Figure 1. Immunohistochemical identification of the cells in vascular grafts. Histologic cross-sections of healing grafts 1 mo after implantation showing endothelial cells (factor VIII specific staining) at the luminal surface (left), macrophages (HAM 56-positive staining) in the graft interstices (middle), and smooth muscle cells (HHF 35-positive cells) in the intima (right). In each micrograph, the luminal surface of the intima (arrowhead) is at the top. (Arrow) The inner boundary of the graft matrix $(G)$. 

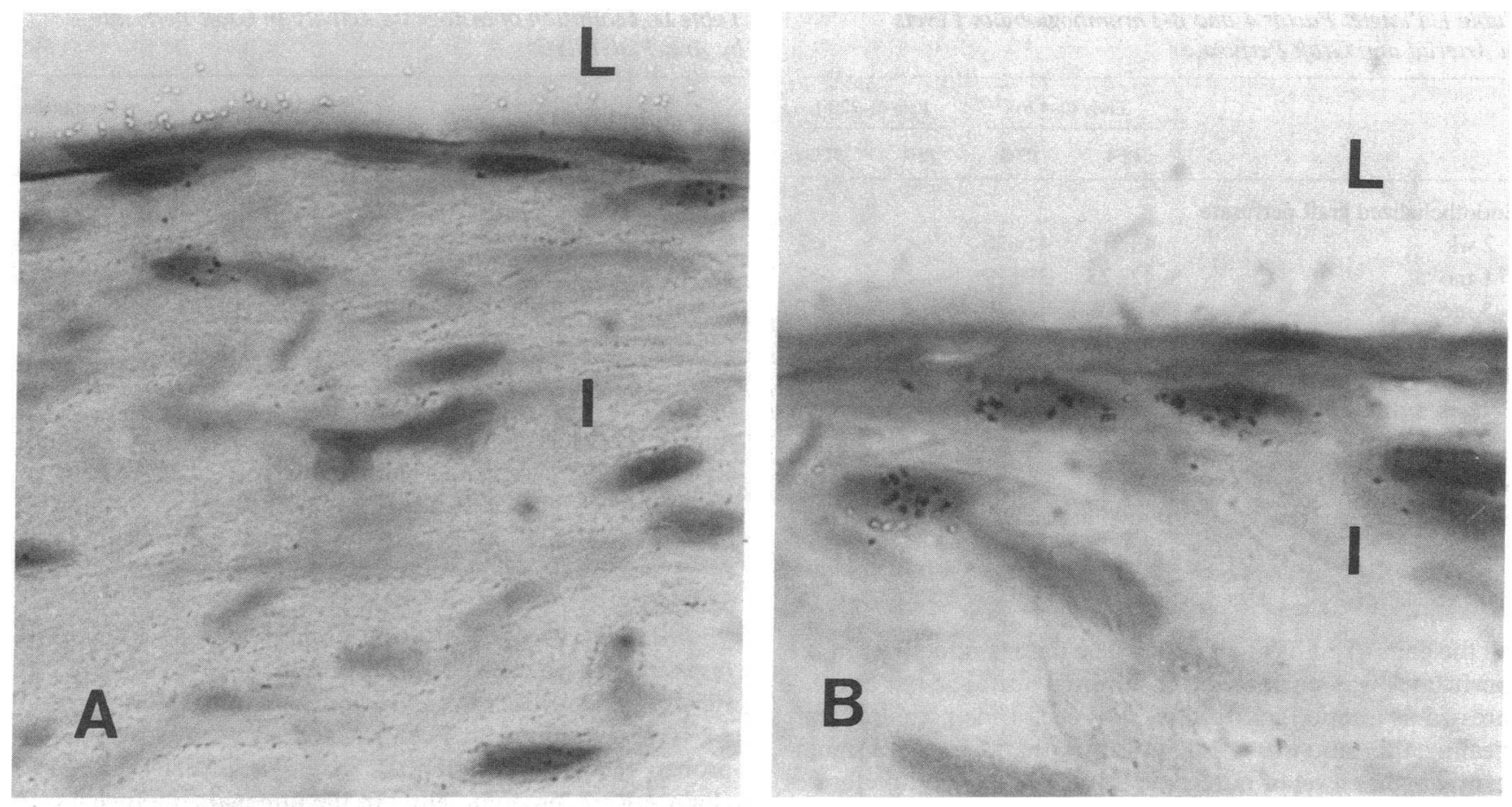

Figure 2. Autoradiograms of cross-sections of healing graft from ${ }^{3} \mathrm{H}$-thymidine-treated baboon at one month. $(A)$ Proliferating intimal SMC with overlying silver grains. $(B)$ Note that most of the labeled SMC are located just under the endothelial surface. $L=$ graft lumen; $I=$ graft intima. $(A) \times 1000 ;(B) \times 2200$.

Ex vivo perfusate contains mitogenic activity. Grafts were excised at various times after placement and perfused ex vivo. Mitogenic activity for human fibroblasts was detected in both graft and artery perfusates. The release of mitogenic activity into the perfusate was evaluated at several points in time during the perfusion ex vivo. Initial collections (at 2-h intervals for the first $6 \mathrm{~h}$ ) contained more mitogenic activity than those obtained at subsequent times (8-22 h). The level of mitogenic activity, however, was constant in collections evaluated between 8 and 22 h (Fig. 3).

Evidence that the mitogenic activity in the perfusate is not derived from necrotic cells or adherent platelets. We were concerned that the release of mitogenic activity into the perfusate might be the result of cell injury or death from surgical graft removal and perfusion. However, scanning electron microscopy demonstrated that the endothelial lining was still present on the luminal surface of the segments of graft and artery after

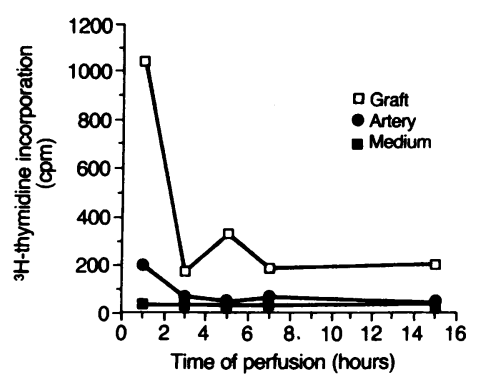

Figure 3. Mitogenic activity in graft perfusate. Time course of release of mitogenic activity for human fibroblasts released into the luminal perfusate during ex vivo perfusion of a representative graft and control artery of similar surface area. Unperfused medium was used as a control. ${ }^{3} \mathrm{H}$-Thymidine

incorporation into DNA was measured (counts per minute) per well as described in Methods in response to perfusates pooled at intervals ( $1 \mathrm{~h}[0-1 \mathrm{~h}], 3 \mathrm{~h}[1-3 \mathrm{~h}], 5 \mathrm{~h}[3-5 \mathrm{~h}], 7 \mathrm{~h}[5-7 \mathrm{~h}]$, and $15 \mathrm{~h}[7-15 \mathrm{~h}])$.
$24 \mathrm{~h}$ of perfusion ex vivo (data not shown). In addition, the perfusates from both graft and artery contained only low levels of LDH activity, an indicator of cellular damage. In contrast, cell death caused by crushing the arterial tissue resulted in a large release of LDH activity into the perfusate (data not shown).

No adherent platelets were observed on the luminal surface of the graft and arterial segments. However, there remained the possibility that the initial measurement of a high level of mitogenic activity in the perfusate might be due to adherent thrombus not successfully rinsed free from the grafts. To investigate this, we measured beta-TG and PF4 levels in the perfusate, because these molecules are constituents of platelet granules and are liberated during the release reaction (Table I). As a positive control, some grafts were removed $1 \mathrm{~h}$ after placement. These grafts exhibited only thrombus on the luminal surface. Perfusates of these 1-h grafts had elevated levels of both PF4 and beta-TG in collections obtained between 0 and $8 \mathrm{~h}$ and 8 and $24 \mathrm{~h}$ of perfusion ex vivo. For grafts and arteries removed at $2 \mathrm{wk}$ and after, some of the perfusate fractions collected between 0 and $4 \mathrm{~h}$ of perfusion contained detectable PF4 and beta-TG levels, suggesting that there might be slight contamination with platelet products. However, PF4 and beta-TG were not present in perfusate fractions collected from either graft or artery between 8 and $22 \mathrm{~h}$ of perfusion (Table I). Therefore, to limit evaluation to perfusates that contained no detectable levels of platelet products, all comparisons of mitogenic activity were performed on perfusate fractions collected between 8 and $22 \mathrm{~h}$ of perfusion ex vivo.

Perfusates from grafts contain more mitogenic activity than perfusates from arteries. Measurements were made of mitogenic activity in the perfusate fractions collected $(8-22 \mathrm{~h})$ from 
Table I. Platelet Factor 4 and $\beta$-Thromboglobulin Levels in Arterial and Graft Perfusate

\begin{tabular}{lcccccc}
\hline & \multicolumn{2}{c}{ Early $(0-4 \mathrm{~h})$} & & \multicolumn{2}{c}{ Late $(8-22 \mathrm{~h})$} \\
\cline { 2 - 3 } & PF4 & $\beta T G$ & & PF4 & $\beta T G$ \\
\hline Endothelialized graft perfusate & & & & & \\
2 wk & $43 \pm 18$ & $41 \pm 20$ & & $<7$ & $<7$ \\
1 mo & $42 \pm 23$ & $37 \pm 12$ & & $<7$ & $<7$ \\
3 mo & $<7$ & $<7$ & & $<7$ & $<7$ \\
Arterial control perfusate & $<7$ & $<7$ & & $<7$ & $<7$ \\
Thrombus-lined graft perfusate & $>100$ & $>200$ & & $30 \pm 4$ & $27 \pm 2$ \\
Baboon serum & $>100$ & $>200$ & $>100$ & $>200$
\end{tabular}

Values for platelet factor 4 (PF4) and $\beta$-thromboglobulin ( $\beta$ TG) are expressed as mean (nanograms per milliliter) $\pm \mathrm{SD}$. In each group, $n$ $=3$.

all the pairs of grafts and arteries. The mitogenic activity in the perfusates was normalized to luminal surface area and expressed as a ratio (graft/artery). For each time period of graft healing, this ratio was $>1.0$, indicating that there was a significantly higher level of mitogenic activity in the graft perfusates than in the control artery perfusates (Fig. $4 ; P \leq 0.05$ ).

Part of the mitogenic activity of the graft perfusate is antigenically related to PDGF. A polyclonal anti-PDGF neutralizing antibody was used to evaluate the contribution of PDGFlike protein to the mitogenic activity of the graft perfusates. Compared to nonimmune IgG, anti-PDGF IgG significantly decreased the mitogenic activity of the graft perfusates. The decrease in mitogenic activity was $\sim 40-45 \%$. The presence of PDGF was confirmed by PDGF radioreceptor assay (data not shown) (26). However, due to the small amounts of PDGF-like protein present in the perfusates, analysis of the levels of PDGF-like protein by radioreceptor assay would have required pooling samples from more than one animal. PDGF-like protein was demonstrated by neutralization of mitogenic activity in perfusates of 2-wk and 1-mo grafts (Table II). Although there was variability between experiments, PDGF-like protein accounted for a significant portion of the mitogenic activity of each graft perfusate in all of the samples.

Expression of PDGF $m R N A$ by graft intimal cells. To determine whether PDGF transcript levels were altered in the grafts, Northern analysis was performed on total cellular RNA extracted from the control arteries and the intimas of the grafts

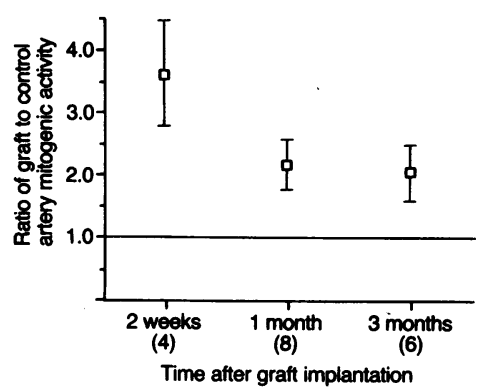

Figure 4. Mitogenic activity of perfusates from grafts removed at different times after transplanation. The mitogenic activity of graft and arterial perfusates was normalized to luminal surface area and expressed as a ratio for each animal studied (mean [\%] \pm SE). At all times ratios of graft to artery activity were $>1(P$ $=0.05$ by nonparametric signed rank test). The number of animals studied at each time period is shown in parenthesis.
Table II. Inhibition of Mitogenic Activity in Graft Perfusate by Anti-PDGF IgG

\begin{tabular}{lcc}
\hline & 2-wk grafts & 1-mo grafts \\
\hline Inhibition of mitogenesis & $45 \pm 11$ & $46 \pm 12$ \\
Range & $13-63$ & $28-69$ \\
& $n=4$ & $n=8$
\end{tabular}

Inhibition of fibroblast mitogenesis $(\%) \pm \mathrm{SE}$ was measured as described in Methods.

(Fig. 5). Low levels of PDGF-B mRNA were detected in both artery and graft samples. In contrast, the graft intima expressed elevated levels of PDGF-A mRNA compared to control arteries (two- to sixfold) as measured by densitometry or multiple exposures of three different mRNA preparations for each time period.

Localization of PDGF $m R N A$ containing cells in grafts by in situ hybridization. To identify cells in the grafts synthesizing PDGF, serial sections from two grafts left in place for 7.5 or 12 wk were hybridized to PDGF-A and -B chain specific riboprobes. In the 12-wk graft we were able to detect PDGF-A chain mRNA predominantly in the lumenal endothelial cells (Fig. 6, $a$ and $c$ ) as well as in occasional intimal SMC (Fig. $6 c$ ). Serial sections of these grafts suggested a weak PDGF-B chain hybridization to the luminal endothelium (Fig. 6, $b$ and $d$ ) but not to the intimal SMC. Similar results were seen in the $7.5 \mathrm{wk}$ graft with detection of PDGF-A chain mRNA in lumenal endothelial cells and in SMC throughout the graft intima (Fig. $6 e$ ). However, we failed to detect any PDGF-B chain mRNA hybridization at this time (Fig. $6 f$ ). At both times, cells containing PDGF-A and -B chain mRNA were detected within the interstices of the porous graft material but were not conclusively identified (data not shown).

\section{Discussion}

In our baboon model of arterial intimal thickening, SMC proliferate beneath an intact endothelium in the absence of adherent platelets. This observation suggests that growth factors for the SMC may originate in the cells of the graft rather than in platelets. This concept is supported by our observations demonstrating in an ex vivo perfusion system that a healing graft releases into the luminal perfusate more mitogenic activity than a normal arterial segment. This mitogenic activity is partially inhibitable by a monospecific anti-PDGF antibody, and Northern analysis of mRNA and in situ hybridization studies show elevated expression of PDGF-A in the graft intima as compared with normal artery. When these results are considered together with our earlier observation, they suggest that the SMC proliferation in this system in vivo is associated with increased expression of PDGF A chain mRNA in the intimal cells and the presence of PDGF-like protein.

$P D G F$ as a regulator of SMC growth. PDGF has been implicated in the regulation of cellular proliferation in vitro and in vivo. This protein growth factor is released in at least three forms, which are the dimeric combinations of two distinct but homologous chains, termed A and B chain. The A and B chains are encoded by separate, independently regulated genes and are 

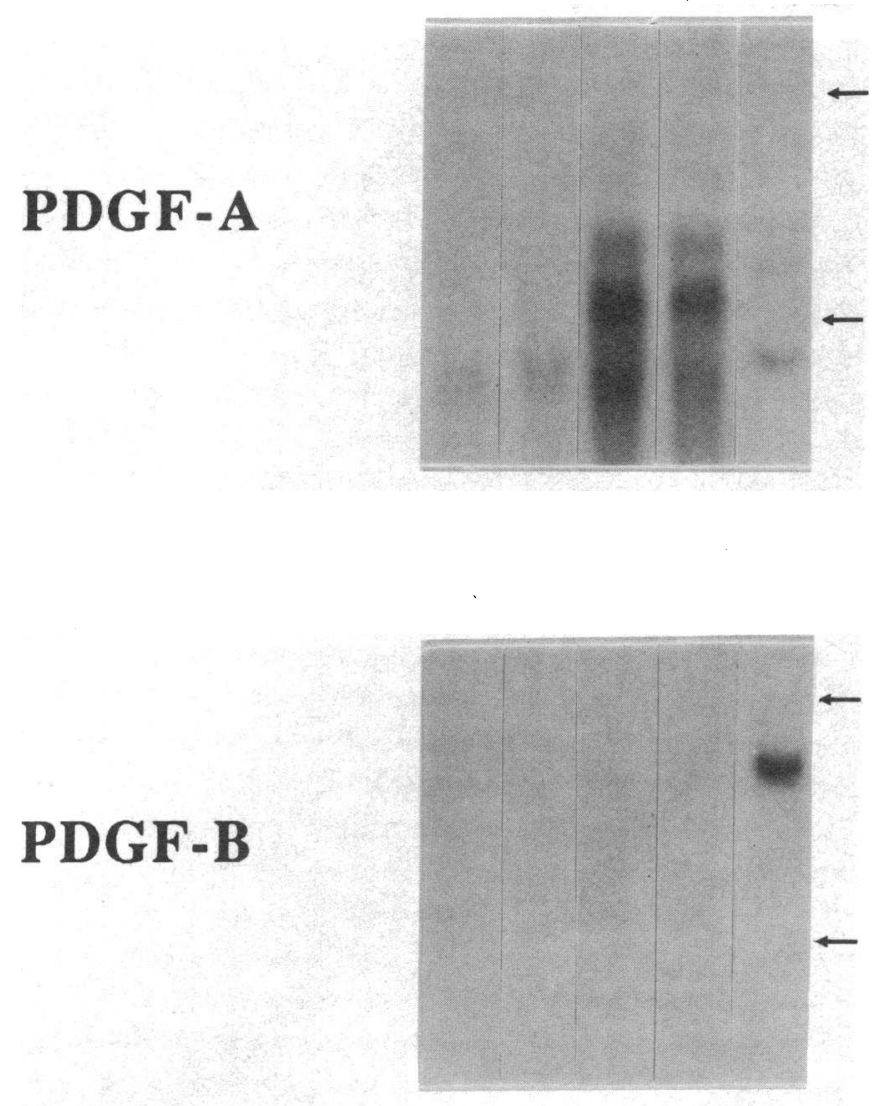

C A $1 \mathrm{~m} 3 \mathrm{~m} \mathrm{P}$

Figure 5. Expression of PDGF mRNA by intimal cells. Total RNA was extracted from normal baboon carotid artery $(C)$ and aorta $(A)$ as well as from intima of 1- and 3-mo grafts and examined on Northern blots for PDGF A and B chain. Each lane contains $10 \mu \mathrm{g}$ of RNA. Graft intimal cells express more PDGF A chain transcript than do arterial SMC. Both tissues express little or no PDGF B-chain transcript. PDGF B-chain expression by culture newborn rat pup aortic SMC $(P)$ is shown as a positive control. Arrows indicate positions of $18 \mathrm{~S}$ and $28 \mathrm{~S}$ ribosomal RNA.

located on different chromosomes (26). PDGF, originally found in platelets, is also secreted in vitro by many different cell types, including endothelial cells, smooth muscle cells, monocyte/macrophages, and numerous transformed cell lines (1, 27).

The expression and secretion of PDGF by normal diploid cells appears to be tightly regulated. For example, bovine aortic or human umbilical vein endothelial cells stripped from blood vessels contain only $10 \%$ and $1.3 \%$, respectively, as much Bchain transcript as the same cells in monolayer culture (28). When endothelium switches from a monolayer to tubelike structures in culture it alters its expression of A- and B-chain mRNA (29-31). Transient expression of PDGF is induced in response to cell activation by coagulation factors and by cytokines, as well as by variations in cell substrate $(1,12,27)$.

The response of SMC to PDGF is affected not only by the abundance of the growth factor but also by the regulated expression of PDGF receptors. For example, it has been demonstrated that there are two different receptor subunits that can combine to create different receptor phenotypes for PDGF (32-35). The alpha-subunit can bind either the A or B chain of PDGF, whereas the beta-subunit can bind only the $B$ chain. Therefore, the response of a given cell depends both on the isoform of PDGF present and the total number and proportion of alpha- and beta-subunits of the receptor present on the cell surface $(26,35)$. To establish that PDGF is indeed the endogenous regulator of intimal SMC proliferation, pharmacological means to block its activity and measurements of receptor function in vivo will be required.

Sources of mitogenic activity. The neointima is largely composed of SMC and is covered with a luminal monolayer of endothelium. Macrophages are rarely present in the intima but reside in large numbers within the interstices of the porous graft material. Therefore, if the cells in the graft are the source of the growth factor that drives the SMC proliferation, then endothelium and SMC appear to be the most likely source because the proliferating SMC are mostly located near the luminal surface. Both cell types in vitro have been shown to secrete growth factors, including PDGF, that are capable of stimulating SMC proliferation $(1,27)$.

The SMC that are proliferating in the intima of the healing grafts are concentrated in the region just beneath the endothelium, and the in situ hybridization studies demonstrate that endothelial cells and adjacent intimal SMC are expressing PDGF A chain mRNA. From these results, it appears that these two cell types are the major source of PDGF which might be responsible for the growth of the underlying SMC. The endothelial cells might synthesize and release factors (36-38), or alternatively, they might interact with the SMC in such a way as to stimulate the SMC to produce their own mitogen. Coculture and conditioned medium experiments in vitro have provided support for these kinds of interactions $(39,40)$.

The mitogenic activity detected in the lumen of the grafts might be only a small fraction of the mitogens available to the intimal SMC. If endothelium and SMC are the sources of PDGF in this model, it seems more likely that they should secrete the growth factor into the matrix than into the lumen. Cultured endothelial cells have been shown to secrete PDGF vectorially into the abluminal, basal compartment (41). The mitogenic activity detected in the graft perfusates might represent activity leached out of the graft matrix. At present we do not have the reagents to determine the dimeric form of PDGF and to localize the protein within the intima.

If the endothelial cell is the source of the mitogen for the SMC, then there must be a difference between the endothelial cells of the graft and the endothelial cells of the artery to account for the differences in expression of mitogenic activity. Scanning microscopy shows that the endothelial cells in the graft are larger than those found in the artery (25). The graft endothelial cells are also proliferating at a higher rate than arterial endothelial cells (9), presumably because of some form of injury $(42,43)$. Endothelial cells turning over at a relatively high rate might be in a different functional state, including production of a mitogen for SMC or mediators capable of inducing the production of growth factors by SMC themselves. Several stimuli have been shown to affect the production of mitogens by endothelial cells in vitro (43-48).

SMC are present in both the artery and the graft intima. If they are in part regulating their own proliferative state $(6,7,14$, 49-51), then differences between the populations of SMC in 

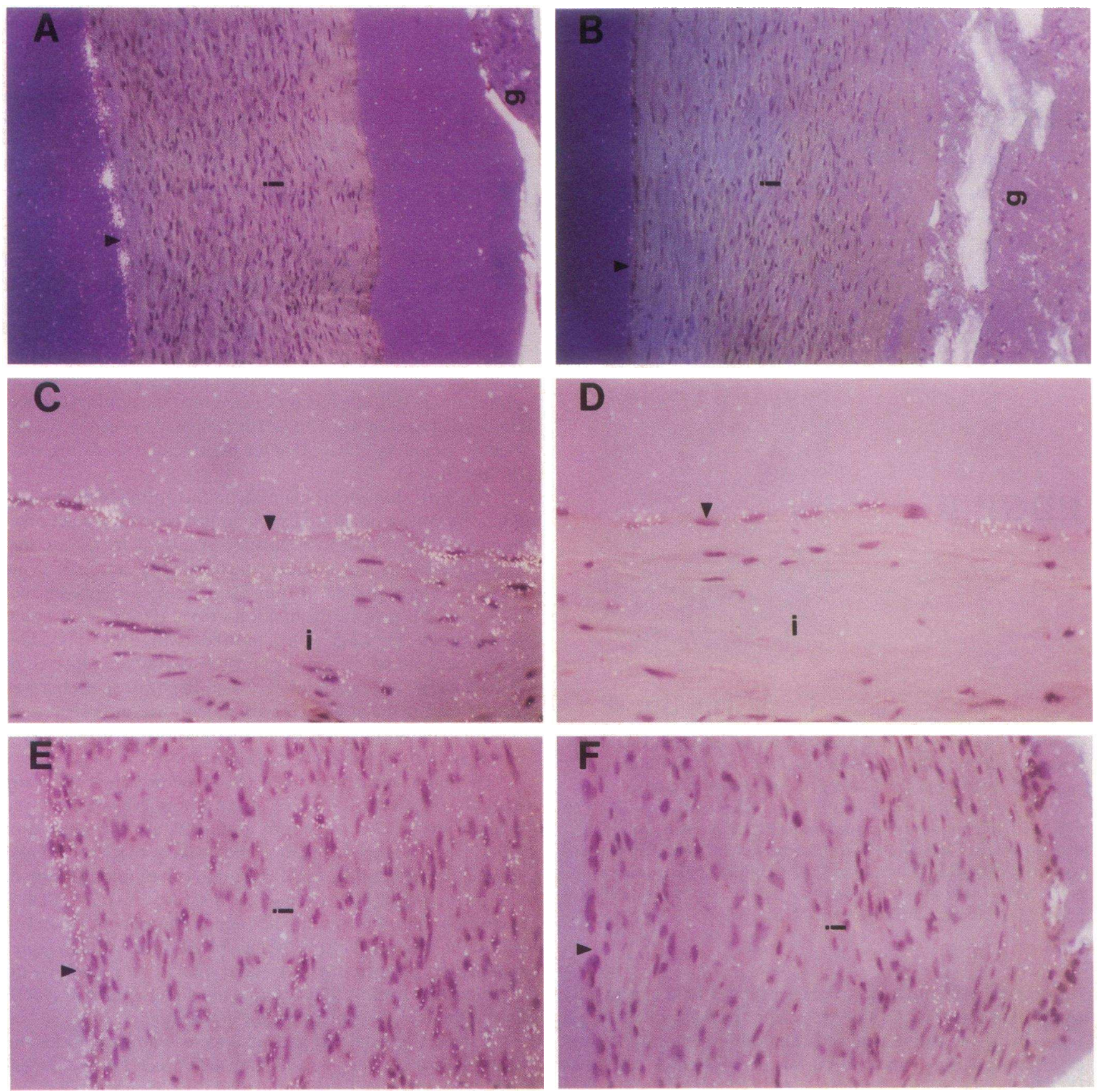

Figure 6. Localization of cells containing PDGF mRNA in healing vascular grafts by in situ hybridization. Serial sections of 12 -wk $(A-D)$ or 7.5-wk $(E$ and $F)$ arterial grafts were hybridized with ${ }^{35}$ S-labeled PDGF-A $(A, C, E)$ or -B $(B, D, F)$ chain specific riboprobes. PDGF-A chain mRNA was detected in endothelial cells $(A, C, D)$ as well as some intimal SMC ( $C$ and $E$ ). PDGF-B chain mRNA was only detected in a few endothelial cells of the $12 \mathrm{wk}(D)$ graft. Specimens were photographed using a combination of polarized light epiluminescence and bright field illumination. Magnification, $(A$ and $B) 125 ;(C-F)$ 310. (Arrowheads) The lumenal surface on each sample. $(i)$ Intima; $(g)$ graft.

the graft intima and neighboring artery, similar to those discussed above for endothelium, might account for the observed differences in proliferation. Differences in shear or wall motion or both between artery and graft may be involved in inducing SMC to proliferate. For example, SMC exposed to cyclic deformation exhibited less proliferation than identical cells cultured under static conditions (52). In addition, although the SMC in the intima stain with anti-alpha actin antibodies as do the aortic SMC, the graft intimal SMC are derived from microvascular sources. Whether SMC of microvascular origin function in the same fashion on a large vessel prosthesis as do the SMC normally found in the media of a large vessel is not known.

The other cell that is abundant in the graft, the macrophage, is known to produce mitogens for $\operatorname{SMC}(11,53)$ and could be 
regulating intimal SMC growth. However, SMC proliferation increases with increasing distance of the SMC from the macrophages in the graft interstices. This observation appears inconsistent with the hypothesis that the macrophage is an important source of SMC mitogen in this model unless one argues for an inverse gradient in which low concentrations of macrophage products stimulate smooth muscle proliferation and high concentrations are inhibitory or that the endothelial cells or their matrix concentrate the macrophage released growth factors.

Other factors possibly affecting SMC proliferation. Because only $50 \%$ of the growth promoting activity is attributed to PDGF-like mitogen, we must consider what other known mitogens might be present and active. A limited number of perfusates were evaluated for the presence of interleukin 1 and transforming growth factor $\beta$; neither of these factors was detected (data not shown). Fibroblast growth factor (FGF) is a particularly good candidate because it is synthesized by endothelial and smooth muscle cells. Although it might not be actively secreted, it is released from disrupted cells $(54,55)$ and stored in the surrounding matrix. Hence, FGF might be released from endothelial cells turning over at the graft surface at the time of cell death and might stimulate adjacent SMC. When administered in pharmacological amounts intravenously, basic FGF is a potent stimulus for regenerating endothelium and SMC in denuded rat carotid artery (56).

The mitogenic activity detected in the graft perfusate reflects the response of the test cells to the combination of stimulatory and inhibitory factors in the perfusate. The presence of inhibitory substances in the perfusate, and in the vessel wall, might also be important determinants of the extent and location of the intimal SMC proliferation in vivo. For example, heparan sulfate secreted by endothelium and SMC inhibits SMC growth in vitro and might be an inhibitor of SMC in vivo $(57,58)$. Latent transforming growth factor-beta activated by endothelium-pericyte interactions has been shown to be an inhibitor of cellular proliferation in vitro (40) and might also be active in vivo.

Our studies suggest that PDGF may be important in the regulation of the SMC proliferation observed in the graft intima. Although we have not identified the specific factors that induce increased PDGF A-chain gene expression in the graft intima, we have observed a difference in the pattern of PDGF A-chain expression and luminal perfusate mitogenic activity in the graft as compared to the control artery. In this organized vascular tissue, the association of intimal SMC proliferation with the presence of intimal PDGF A-chain mRNA expression and release of PDGF-like protein supports the concept that factors from the cells in the intima rather than platelets may regulate intimal SMC proliferation.

\section{Acknowledgments}

The authors thank Dr. Stephen R. Hanson for performing the $\beta$ thromboglobulin and platelet factor 4 assays, Andrew Augustine for help with the in situ hybridization studies, and Patricia Bartnick for her assistance in the preparation of the manuscript.

These studies were supported by grants HL30946, HL18645, and RR00166 from the National Institutes of Health, United States Public Health Service and by a grant from the American Heart Association, Washington Affiliate to Michael A. Golden. These studies were conducted in the Regional Primate Research Center at the University of Washington.

\section{References}

1. Ross, R., E. W. Raines, and D. F. Bowen-Pope. 1986. The biology of platelet-derived growth factor. Cell. 46:155-169.

2. Barrett, T. B., and E. P. Benditt. 1987. sis (platelet-derived growth factor B chain) gene transcript levels are elevated in human atherosclerotic lesions compared to normal artery. Proc. Natl. Acad. Sci. USA. 84:1099-1103.

3. Barrett, T. B., and E. P. Benditt. 1988. Platelet-derived growth factor gene expression in human atherosclerotic plaques and normal artery wall. Proc. Natl. Acad. Sci. USA. 85:2810-2814.

4. Ross, R., J. Masuda, E. W. Raines, A. M. Gown, S. Katsuda, M. Sasahara, L. T. Malden, H. Masuko, and H. Sato. 1990. Localization of PDGF protein in macrophages in all phases of atherogenesis. Science (Wash. DC). 248:1009-1012.

5. Wilcox, J. N., K. M. Smith, L. T. Williams, S. M. Schwartz, and D. Gordon. 1988. Platelet-derived growth factor mRNA detection in human atherosclerotic plaques by in situ hybridization. J. Clin. Invest. 82:1134-1143.

6. Majesky, M. W., M. A. Reidy, D. F. Bowen-Pope, C. E. Hart, J. M. Wilcox, and S. M. Schwartz. 1990. PDGF ligand and receptor gene expression during repair of arterial injury. J. Cell Biol. 111:2149-2158.

7. Libby, P., S. J. C. Warner, R. N. Salomon, and L. K. Birinyi. 1988. Production of platelet-derived growth factor-like mitogen by smooth muscle cells from human atheroma. N. Engl. J. Med. 318:1493-1498.

8. Rubin, K., G. K. Hansson, L. Ronnstrand, L. Claesson-Welsh, B. Fellstrom, A. Tingstrom, E. Larsson, L. Klareskog, C.-H. Heldin, and L. Terracio. 1988. Induction of B-type receptors for platelet-derived growth factor in vascular inflammation: possible implications for development of vascular proliferative lesions. Lancet. 8599:1353-1356.

9. Clowes, A. W., T. R. Kirkman, and M. A. Reidy. 1986. Mechanisms of arterial graft healing. Rapid transmural capillary ingrowth provides a source of intimal endothelium and smooth muscle in porous PTFE prostheses. Am. J. Pathol. 123:220-230.

10. Raines, E. W., and R. Ross. 1985. Purification of human platelet-derived growth factor. Methods Enzymol. 109:749-772.

11. Shimokado, K., E. W. Raines, D. K. Madtes, T. B. Barrett, E. P. Benditt, and R. Ross. 1985. A significant part of macrophage-derived growth factor consists of at least two forms of PDGF. Cell. 43:277-286.

12. Raines, E. W., S. K. Dower, and R. Ross. 1989. IL-1 mitogenic activity for fibroblasts and smooth muscle cells is due to PDGF-AA. Science (Wash. DC.). 243:393-396.

13. Cathala, G., J. F. Savouret, and B. Mendez. 1983. A method for isolation of intact translationally active ribonucleic acid. DNA. 2:329-335.

14. Majesky, M. W., E. P. Benditt, and S. M. Schwartz. 1988. Expression and developmental control of platelet-derived growth factor A-chain and B-chain/sis genes in rat aortic smooth muscle cells. Proc. Natl. Acad. Sci. USA. 85:15241528 .

15. Betsholtz, C., A. Johnsson, C.-H. Heldin, B. Westermark, P. Lind, M. S., Urdea, R. Eddy, T. B. Showes, K. Philpott, A. L. Mellor, T. J. Knott, and J. Scott. 1986. cDNA sequence and chromosomal localization of human platelet-derived growth factor A-chain and its expression in tumour cell lines. Nature (Lond.). 320:695-699.

16. Robbins, K. C., S. G. Devare, and S. A. Aaronson. 1981. Molecular cloning of integrated simian sarcoma virus: genome organizations of infectious DNA clones. Proc. Natl. Acad. Sci. USA. 78:2918-2922.

17. Maniatis, T., E. F. Fritsch, and J. Sambrook, editors. 1982. Molecular Cloning: A Laboratory Manual. Cold Spring Harbor Laboratory, Cold Spring Harbor, NY. 109-112.

18. Josephs, S. F. L. Ratner, M. F. Clarke, E. H. Westin, M. S. Reitz, and F. Wong-Staal. 1984. Transforming potential of human c-sis nucleotide encoding platelet-derived growth factor. Science (Wash. DC). 225:636-639.

19. Melton, D. A., P. A. Krieg, M. R. Rebagliati, T. Maniatis, K. Zinn, and M. R. Green. 1984. Efficient in vitro synthesis of biologically active RNA and RNA hybridization probes from plasmids containing a bacteriophage SP6 promoter. Nucleic Acids Res. 12:7035-7056.

20. Wilcox, J. N., K. M. Smith, S. M. Schwartz, and D. Gordon. 1989. Localization of tissue factor in the normal vessel wall and in the atherosclerotic plaque. Proc. Natl. Acad. Sci. USA. 86:2839-2843.

21. Clowes, A. W., A. M. Gown, S. R. Hanson, and M. A. Reidy 1985. Mechanisms of arterial graft failure. I. Role of cellular proliferation in early healing of PTFE prostheses. Am. J. Pathol. 118:43-54.

22. Gown, A. M., and A. M. Vogel. 1984. Monoclonal antibodies to intermediate filament proteins of human cells. II. Distribution of filament proteins in normal human tissue. Am. J. Pathol. 114:309-321.

23. Turner, R. R., J. H. Beckstead, R. A. Warnke, and G. S. Wood. 1987. Endothelial cell phenotypic diversity. Am. J. Clin. Pathol. 87:569-575.

24. Tsukada, T., D. Tippens, D. Gordon, R. Ross, and A. M. Gown. 1987. HHF-35, a muscle-actin-specific monoclonal antibody. Am. J. Pathol. 126:5160.

24a. Gown, A. M., T. Tsukada, and R. Ross. 1986. Human atherosclerosis. II. 
Immunocytochemical analysis of the cellular composition of human atherosclerotic lesions. Am. J. Pathol. 125:191-207.

25. Clowes, A. W., T. R. Kirkman, and M. M. Clowes. 1986. Mechanisms of arterial graft failure. II. Chronic endothelial and smooth muscle cell proliferation in healing polytetrafluoroethylene prostheses. J. Vasc. Surg. 3:877-884.

26. Bowen-Pope, D. F., C. E. Hart, and R. A. Seifert. 1989. Sera and conditioned media contain different isoforms of platelet-derived growth factor (PDGF) which bind to different classes of PDGF receptor. J. Biol. Chem. 264:2502-2508.

27. Raines, E. W., D. F. Bowen-Pope, and R. Ross. 1989. Platelet-derived growth factor. In Handbook of Experimental Pharmacology: Peptide Growth Factors and Their Receptors. M. B. Sporn and A. B. Roberts, editors. SpringerVerlag, Heidelberg, FRG. Vol. 952

28. Barrett, T. B., C. M. Gajdusek, S. M. Schwartz, J. K. McDougall, and E. P. Benditt. 1984. Expression of the sis gene by endothelial cells in culture and in vivo. Proc. Natl. Acad. Sci. USA. 81:6772-6774.

29. Jaye, M., E. McConathy, W. Drohan, B. Tong, T. Deuel, and T. Maciag. 1985. Modulation of the sis gene transcript during endothelial cell differentiation in vivo. Science (Wash. DC). 228:882-885.

30. Tong, B. D., D. E. Auer, M. Jaye, J. M. Kaplow, G. Ricca, E. McConathy, W. Drohan, and T. F. Deuel. 1987. cDNA clones reveal differences between human glial and endothelial cell platelet-derived growth factor A-chains. Nature (Lond.). 328:619-621.

31. Starksen, N. F., G. R. Harsh, V. C. Gibbs, and L. T. Williams. 1987. Regulated expression of the platelet-derived growth factor A-chain gene in microvascular endothelial cells. J. Biol. Chem. 262:14381-14384.

32. Heldin, C.-H., G. Backstrom, A. Ostman, A. Hammacher, L. Ronnstrand, K. Rubin, M. Nister, and B. Westermark. 1988. Binding of different dimeric forms of PDGF to human fibroblasts: evidence for two separate receptor types. EMBO (Eur. Mol. Biol. Organ.) J. 7:1387-1393.

33. Hart, C. E., J. W. Forstrom, J. D. Kelly, R. A. Seifert, R. A. Smith, R. Ross, M. J. Murray, and D. F. Bowen-Pope. 1988. Two classes of PDGF receptor recognize different isoforms of PDGF. Science (Wash. DC). 240:1529-1531.

34. Matsui, T., M. Heidaran, T. Miki, N. Popescu, W. LaRochelle, M. Kraus, J. Pierce, and S. Aaronson. 1989. Isolation of a novel receptor cDNA establishes the existence of two PDGF receptor genes. Science (Wash. DC). 243:800-804.

35. Siefert, R. A., C. E. Hart, P. E. Phillips, J. W. Forstrom, R. Ross, M. J. Murray, and D. F. Bowen-Pope. 1989. Two different subunits associate to create isoform-specific platelet-derived growth factor receptors. J. Biol. Chem. 264:8771-8778

36. DiCorleto, P. E., and D. F. Bowen-Pope. 1983. Cultured endothelial produce a platelet-derived growth factor-like protein. Proc. Natl. Acad. Sci. USA 80:1919-1923

37. Collins, T. D., T. Bonthron, and S. H. Orkin. 1987. Alternative RNA splicing affects function of encoded platelet-derived growth factor A chain. $\mathrm{Na}$ ture (Lond.). 328:621-624.

38. Collins, T., J. S. Pober, M. A. Gimbrone, Jr., A. Hammacher, C. Betsholtz, B. Westermark, and C.-H. Heldin. 1987. Cultured human endothelial cells express platelet-derived growth factor A chain. Am. J. Pathol. 126:7-12.

39. Ganz, P., P. F. Davies, J. A. Leopold, M. A. Gimbrone, Jr., and R. W. Alexander. 1986. Short- and long-term interactions of endothelium and vascular smooth muscle in coculture: effects on cyclic GMP production. Proc. Natl. Acad. Sci. USA. 83:3552-3556.

40. Orlidge, A., and P. A. D'Amore. 1987. Inhibition of capillary endothelia cell growth by pericytes and smooth muscle cells. J. Cell Biol. 105:1455-1462.
41. Zerwes, H.-G., and W. Risau. 1987. Polarized secretion of a platelet-derived growth factor-like chemotactic factor by endothelial cells in vitro. $J$. Cell Biol. 105:2037-2041.

42. Hansson, G. K., S. Chao, S. M. Schwartz, and M. A. Reidy. 1985. Aortic endothelial cell death and replication in normal and lipopolysaccharide-treated rats. Am. J. Pathol. 121:123-127.

43. Hajjar, K. A., D. P. Hajjar, R. L. Silverstein, and R. L. Nachman. 1987. Tumor necrosis factor-mediated release of platelet-derived growth factor from cultured endothelial cells. J. Exp. Med. 166:235-245.

44. Kavanaugh, W. M., G. R. Harsh, N. F. Starksen, C. M. Rocco, and L. T. Williams. 1988. Transcriptional regulation of the $A$ and $B$ chain genes of PDGF in microvascular endothelial cells. J. Biol. Chem. 263:8470-8472.

45. Daniel, T. O., V. C. Gibbs, D. F. Milfay, M. R. Garovoy, and L. T. Williams. 1986. Thrombin stimulates c-sis gene expression in microvascular cells. J. Biol. Chem. 261:9579-9582.

46. Harlan, J. M., P. J. Thompson, R. Ross, and D. F. Bowen-Pope. 1986. Alpha thrombin induces release PDGF-like molecule(s) by cultured human endothelial cells. J. Cell Biol. 103:1129-1133.

47. Fox, P. L., and P. E. DiCorleto. 1984. Regulation of production of a platelet-derived growth factor-like protein by cultured bovine aortic endothelial cells. J. Cell Physiol. 121:298-308.

48. Fox, P. L., and P. E. DiCorleto. 1986. Modified low density lipoproteins suppress production of a platelet-derived growth factor-like protein by cultured endothelial cells. Proc. Natl. Acad. Sci. USA 83:4774-4778.

49. Seifert, R. A., S. M. Schwartz, and D. F. Bowen-Pope. 1984. Developmentally regulated production of platelet-derived growth factor-like molecules. $\mathrm{Na}$ ture (Lond.). 311:669-671.

50. Nilsson, J., M. Sjolund, L. Palmberg, J. Thyberg, and C.-H. Heldin. 1985. Arterial smooth muscle cells in primary culture produce a platelet-derived growth factor-like protein. Proc. Natl. Acad. Sci. USA. 82:4418-4422.

51. Walker, L. N., D. F. Bowen-Pope, R. Ross, and M. A. Reidy. 1986 Production of platelet-derived growth factor-like molecules by cultured arterial smooth muscle cells accompanies proliferation after arterial injury. Proc. Natl. Acad. Sci. USA. 83:7311-7315.

52. Sumpio, B. E., and A. J. Banes. 1988. Response of porcine aortic smooth muscle cells to cyclic tensional deformation in culture. J. Surg. Res. 44:696-701.

53. Martinet, Y., P. B. Bitterman, J.-F Mornex, G. R. Grotendorst, G. R. Martin, and R. G. Crystal. 1986. Activated human monocytes express the c-sis proto-oncogene and release a mediator showing PDGF-like activity. Nature (Lond.). 319:158-160.

54. Gajdusek, C. M., and S. Carbon. 1989. Injury-induced release of basic fibroblast growth factor from bovine aortic endothelium. J. Cell Physiol. 139:570-579.

55. McNeil, P. L. L Muthukrishnan, E Warder, and P. A. D'Amore. 1989. Growth factors are released by mechanically wounded endothelial cells. J. Cell Biol. 109:811-822.

56. Lindner, V., R. A. Majack, and M. A. Reidy, 1990. Basic FGF stimulates endothelial regrowth and proliferation in denuded arteries. J. Clin. Invest. 85:2004-2008.

57. Fritze, L. M. S., C. F. Reilly, and R. D. Rosenberg. 1985. An antiproliferative heparan sulfate species produced by postconfluent smooth muscle cells. $J$. Cell Biol. 100:1041-1049.

58. Castellot, J. J., Jr., M. L. Addonizio, R. Rosenberg, and M. J. Karnovsky. 981. Cultured endothelial cells produce a heparin-like inhibitor of smooth muscle cell growth. J. Cell Biol. 90:372-379. 